\title{
EFFECTIVENESS OF BRONCHODILATOR AND CORTICOSTEROID TREATMENT IN PATIENTS WITH CHRONIC OBSTRUCTIVE PULMONARY DISEASE (COPD)
}

\author{
Putu Rika Veryanti ${ }^{1 *}$, Ainun Wulandari ${ }^{1}$ \\ ${ }^{1}$ Department of Pharmacy, Institut Sains dan Teknologi Nasional, Jakarta, Indonesia \\ Corresponding author email: rika_veryanti@istn.ac.id
}

\begin{abstract}
Background: Chronic Obstructive Pulmonary Disease (COPD) is a chronic airway disease which is characterized by progressive airway obstruction. Bronchodilators and corticosteroids are the first choices of therapy in COPD patients. The goal therapy of COPD patients is to prevent respiratory failure, which can impact on death. But nowadays, the mortality rate due to COPD continues to increase. WHO predicts mortality from COPD in the year 2030 will be ranked third in the world. This high mortality can be caused by the ineffectiveness of therapy given. Objective: The aim of this study is to find out the effectiveness of bronchodilator and corticosteroid treatments in COPD patients. Methods: An observational study conducted retrospectively in the 2018 period at Fatmawati Central General Hospital. The effectiveness of therapy was assessed from the patient's clinical condition, blood gas values $\left(\mathrm{PaO}_{2} \& \mathrm{PaCO}_{2}\right)$ and the average length of stay (AvLOS). Results: COPD was mostly suffered by males $(83,33 \%)$, and the highest age for COPD was in the range of 45 years and above $(90 \%)$. Bronchodilator that commonly prescribed were albuterol $(30.08 \%)$, ipratropium bromide (12.2\%), fenoterol hydrobromide $(10.57 \%)$, terbutaline sulfate $(8.13 \%)$, theophylline $(1.63 \%)$ and aminophylline (5.69\%), while the corticosteroids were budesonide (17.07\%), methylprednisolone $(9.76 \%)$ and dexamethasone $(4.88 \%)$. Bronchodilator and corticosteroid had improved patient's clinical condition (96.67\% patients) and also improved $\mathrm{PaO}_{2} \& \mathrm{PaCO}_{2}$ values patients. There was a significant improvement in $\mathrm{PaO} 2$ and $\mathrm{PaCO} 2$ value in $\mathrm{COPD}$ patients ( $\mathrm{p}<0.05$ ). Conclusion: Bronchodilator and corticosteroid in COPD patients had improved patient's clinical condition and $\mathrm{PaO}_{2} \& \mathrm{PaCO}_{2}$ values, but the average length of stay exceeds the standard (6-9 days).
\end{abstract}

Keywords: Bronchodilator, Corticosteroid, COPD, Blood Gas Analysis, Average Length of Stay

\section{INTRODUCTION}

Chronic Obstructive Pulmonary Disease (COPD) is a chronic airway disease that is characterized by slow and progressive airflow. COPD is one of the major health problems that could increase morbidity. ${ }^{[1,2]}$ The appropriate therapy is expected to reduce morbidity and mortality in COPD patients. The goal therapy of COPD patients is to prevent respiratory failure, which impacts on death.
Bronchodilators and corticosteroids are the first choices drugs used in patients with COPD. Bronchodilators could relax the smooth muscle in the airway and increase lung emptying while corticosteroid suppresses the inflammation. ${ }^{[3]}$

But unfortunately, the death rate due to COPD continues to increase. The World Health Organization (WHO) estimates deaths from COPD in the world will be - 
ranked third after coronary heart disease in $2030 .{ }^{[1]}$ One of the causes of high mortality due to COPD is the ineffective therapy of COPD. Ineffective therapy can be caused by drug-related problems. ${ }^{[4]}$ A preliminary study has been conducted at Fatmawati Central General Hospital. The study found out the inappropriateness of bronchodilators and corticosteroids treatment in COPD patients. The study showed that there were some discrepancies in the treatment. Six percent in the dose, $3 \%$ in the route of administration and $6 \%$ in the choice of drug. ${ }^{[5]}$ Another problem that could cause ineffectiveness of drug use in COPD is the characteristics of patients such as age, comorbidities and disease severity. Ineffective drug therapy reduces clinical outcomes and increases patient cost. ${ }^{[6,7]}$

Evaluation of the effectiveness of bronchodilators and corticosteroids treatment in COPD patients is an initial step to overcome these problems. The aim of this study is to find out the effectiveness of bronchodilator and corticosteroid treatments in COPD patients. Effective treatment could reduce patient costs so that the rational use of drugs can be realized.

\section{METHODS}

The research was a descriptive study with the use of secondary data obtained by a retrospective method. Data was collected at Fatmawati Central General Hospital in May to June 2019. Samples used in this study were 30 patients, which meet the inclusion criteria, such as in patients with a diagnosis of COPD and received bronchodilator and corticosteroid therapy in the 2018 period. Patients with incomplete data in the medical record were excluded from the study. The obtained data were patient characteristics, bronchodilator and corticosteroid treatment, patient's clinical condition, the value of blood gas examination and length of stay of the patient. Analysis of the effectiveness of bronchodilators and corticosteroids treatment was performed by calculating the percentage of patients who had improved clinical conditions, blood gas values $(\mathrm{PaO} 2$ and $\mathrm{PaCO} 2$ ) and also by calculating the average length of stay (AvLOS) of patients in the hospital.

\section{RESULTS AND DISCUSSION}

\section{A. Patients Characteristic}

The results showed that the prevalence of COPD in males was higher than females. The smoking lifestyle in males affects the rate of COPD prevalence. Smoking is known to be a major risk factor for COPD. Based on the results of Indonesia Basic Health Research (2013), the proportion of male smokers aged $\geq 15$ years was $64.9 \%$, while the proportion of female smokers was only $2.1 \%$. Female smokers considered to have negative behavior based on social norms. Smoking changes in the structure and function of the respiratory tract and lung tissue. Smoking will decline the lung function. Aside from gender, age also influences the prevalence of COPD. ${ }^{[8]}$

Table 1. Patient's Characteristics

\begin{tabular}{|c|l|c|c|}
\hline No & \multicolumn{1}{|c|}{ Variable } & \multicolumn{1}{c|}{ Patients (n) } & Percentage (\%) \\
\hline 1 & Gender & 25 & 83.33 \\
\hline & Male & 5 & 16.67 \\
\hline & Female & $\mathbf{3 0}$ & $\mathbf{1 0 0}$ \\
\hline & Total & \multicolumn{3}{|c|}{} \\
\hline 2 & Age & 3 & 10 \\
\hline & $36-45$ years old & 1 & 3.33 \\
\hline & $46-55$ years old & 12 & 40 \\
\hline & $56-65$ years old & 14 & $\mathbf{1 0 0}$ \\
\hline & $>65$ years old & $\mathbf{3 0}$ & \\
\hline & Total & & \\
\hline
\end{tabular}


Table 1 showed that COPD was mostly sufferers by patients aged above 45 years old. Cardio-respiration endurance increases from childhood and reaches its peak at the age of 20-30 years. After this age, cardiorespiration endurance will decrease. The decrease occurs because of the lungs, heart, and blood vessels begin to decline in function. It's due to the decreased elasticity of the lung parenchyma. ${ }^{[1]}$

\section{B. The use of Bronchodilator and Corticosteroid in COPD Patients}

The use of bronchodilators and corticosteroids in COPD patients at Fatmawati Central General Hospital shown in table 2. Based on the table, the bronchodilators which commonly prescribed for COPD patients were albuterol, ipratropium bromide, fenoterol hydrobromide, terbutaline sulfate, theophylline and aminophylline, while in the group of corticosteroid were budesonide, methylprednisolone and dexamethasone.

Bronchodilators are divided into two main classes, SABA (short-acting $\beta 2$ agonists) and SAMA (short-acting muscarinic antagonist). Both could be given in a single form or in combination for patients with limited activity. But treatment with bronchodilators (SAMA and SABA) is not recommended given routinely to patients with a history of exacerbations or patients with persistent symptoms. The use of bronchodilators improves symptoms by reducing pulmonary hyperinflation and inspiring muscle efficiency. ${ }^{[9]}$ The use of bronchodilators gives several benefits, including accelerating the healing time during acute exacerbations, improving lung function and also shorten the length of stay in the hospital. ${ }^{[10]}$

In COPD patients with acute exacerbations, there is an increase in the systemic inflammatory response, whereby the use of systemic corticosteroids is effective. ${ }^{[10]}$ Corticosteroids are one of the drugs commonly used in the treatment of both reversible and irreversible airway diseases. Inhaled corticosteroids (ICS) are usually used as a treatment of COPD for 34 weeks. Inhaled corticosteroids are also able to reduce exacerbations if used in combination with inhalation LABA. ${ }^{[1]}$

\section{Effectiveness of Bronchodilator and Corticosteroid Treatment in COPD patients}

The effectiveness of bronchodilators and corticosteroids in COPD patients was assessed from the patient's clinical condition, blood gas values $(\mathrm{PaO} 2$ and $\mathrm{PaCO} 2$ ) and the average length of stay of the patient. Table 3 showed that $96.67 \%$ of patients experienced improved clinical conditions. Initial symptoms of patients when hospitalized were coughing, shortness of breath, chest pain and fever. Pathological changes of COPD are found in large airways, small airways, pulmonary parenchyma and pulmonary vascular.

Table 2. Bronchodilators and Corticosteroids Treatment

\begin{tabular}{|c|l|c|c|}
\hline No & \multicolumn{1}{|c|}{ Drug } & \multicolumn{2}{|c|}{ Patients (n) } \\
\hline 1 & Corticosteroids & 12 & 9.76 \\
\hline & Metil Prednisolon & 6 & 4.88 \\
\hline & Dexamethasone & 21 & 17.07 \\
\hline & Budesonide & \multicolumn{3}{|c|}{} \\
\hline 2 & Bronchodilators & 37 & 30.08 \\
\hline & Albuterol & 13 & 10.57 \\
\hline & Fenoterol HBr & 7 & 5.69 \\
\hline & Aminophylline & 15 & 12.2 \\
\hline & Ipratropium bromide & 10 & 8.13 \\
\hline & Terbutaline sulfate & 2 & 1.63 \\
\hline & Theophylline & $\mathbf{1 2 3}$ & $\mathbf{1 0 0}$ \\
\hline & Total & & \\
\hline
\end{tabular}


Table 3. Patient's clinical conditions

\begin{tabular}{|c|l|c|c|}
\hline No & \multicolumn{1}{|c|}{ Clinical Conditions } & Initial (n) & Final (n) \\
\hline 1 & Shortness of breath + Coughing + Fever & 2 & 0 \\
\hline 2 & Shortness of breath + Coughing + Chest pain & 2 & 0 \\
\hline 3 & Shortness of breath + Coughing & 14 & 0 \\
\hline 4 & Shortness of breath + Chest pain & 2 & 1 \\
\hline 5 & Shortness of breath & 10 & $\mathbf{1}$ \\
\hline \multicolumn{2}{|c|}{ Total } & $\mathbf{3 0}$ & 0 \\
\hline
\end{tabular}

Inflammatory cells infiltrate the surface of the central airway epithelium, resulting in the change of epithelium to squamous metaplasia. Mucous gland enlargement and goblet cell increase. These changes result in mucous hypersecretion. Mucus hypersecretion causes a chronic productive cough. The dysfunction of cilia will complicate the expectoration process and cause airway obstruction. Chronic cough is the first symptom in the development of COPD. But it is often ignored by patients because considered as a consequence of smoking or environmental exposure. Initially, the cough can disappear but then persists. Chronic cough is not always accompanied by sputum production. In some cases, airflow resistance could develop without coughing. On the other hand, the changes in the small airways due to inflammation also cause airway remodeling and narrows the non-reversible airway lumen. Inflammation, fibrosis and exudate will cause small airway obstruction, which is a manifestation of shortness of breath that occurs in COPD patients. $^{[12-14]}$

The use of bronchodilator and corticosteroid in COPD patients could prevent respiratory failure. Respiratory failure could be caused by oxygenation disorders, carbon dioxide disruption, or both. Arterial blood gas (ABG) is one of the tests to diagnose lung disease. The partial pressure of oxygen $(\mathrm{PaO} 2)$ and the partial pressure of carbon dioxide $(\mathrm{PaCO} 2)$ were measured to evaluate how well the oxygen $(\mathrm{O} 2)$ and carbon dioxide $(\mathrm{CO} 2)$ moves from the lungs into the blood. The normal value for $\mathrm{PaO} 2$ is between $75-100 \mathrm{mmHg}$, and the normal value for $\mathrm{PaCO} 2$ is $35-45 \mathrm{mmHg}$.
For clinical purposes, respiratory failure is defined as arterial oxygen pressure $(\mathrm{PaO} 2)$ less than $60 \mathrm{mmHg}$ and / or arterial carbon dioxide pressure $(\mathrm{PaCO} 2)$ greater than 45 mmHg. ${ }^{[14]}$

Table 4 showed that there was a significant improvement of $\mathrm{PaO} 2$ and $\mathrm{PaCO} 2$ value in COPD patients $(\mathrm{p}<0.05)$. Patients with a high initial $\mathrm{PaO} 2$ value (above normal) experienced a decrease of $\mathrm{PaO} 2$ value $(\mathrm{p}=0.027175)$, while the patient with a low initial $\mathrm{PaO} 2$ value (below normal) also experienced improvement condition by increasing $\mathrm{PaO} 2$ value $(\mathrm{p}=0.012955)$. The improvement of $\mathrm{PaCO} 2$ patients before and after the treatment also showed significantly $(\mathrm{p}=0.023548$ for patients with initial $\mathrm{PaCO} 2$ above normal and $p=0.002707$ for patients with initial paCO 2 below normal). The average change of $\mathrm{PaO} 2$ patients was $54.24 \mathrm{mmHg}$, and $\mathrm{PaCO} 2$ was $16.88 \mathrm{mmHg}$.

Another indicator that also showed the effectiveness of treatment is the length of stay of the patient. According to the Ministry of Health Republic Indonesia, the average length of stay is ideal between 6-9 days. In this study, $50 \%$ of patients were in the range of ideal AvLOS. But the average length of stay of COPD patients in Hospital exceeded the standards (11.4 days). The length of stay in COPD patients could be affected by the presence of comorbidities. Comorbidity is often cause of death in patients with COPD in the hospital. The length of days of treatment tends to increase in line with the worsening condition and severity of COPD cases. The average length of stay of a COPD patient is shorter at a mild severity compared with a more severe severity. ${ }^{[15]}$ 
Table 4. Pair t-test before and after treatment

\begin{tabular}{|l|c|c|}
\hline \multicolumn{1}{|c|}{ Initial condition } & p-value PaO2 (initial-final) & p-value PaCO2 (initial-final) \\
\hline$<$ Normal & 0.01 & 0.003 \\
\hline Normal & 0.32 & 0.11 \\
\hline$>$ Normal & 0.03 & 0.02 \\
\hline
\end{tabular}

Table 5. Average Length of Stay (AvLOS)

\begin{tabular}{|l|c|c|}
\hline \multicolumn{1}{|c|}{ Length of Stay (days) } & Patients (n) & Percentage (\%) \\
\hline$<6$ & 2 & 6.67 \\
\hline $6-9$ & 15 & 50 \\
\hline$>9$ & 13 & 43.33 \\
\hline Total & $\mathbf{3 0}$ & $\mathbf{1 0 0}$ \\
\hline Average & $\mathbf{1 1 . 4}$ & - \\
\hline
\end{tabular}

\section{CONCLUSION}

Bronchodilator and corticosteroid in COPD patients at Fatmawati Central General Hospital had improved the patient's clinical condition and blood gas values significantly, but the average length of stay exceeds the standard.

\section{CONFLICT OF INTEREST}

No conflict of interset in this paper. This paper was written independently without being affiliated by another party.

\section{ACKNOWLEDGMENT}

We would like to thank The Ministry of Research, Technology and Higher Education of Republik Indonesia for supporting the study. We also thank to Department of Education and Research of Fatmawati Central General Hospital for the cooperation in this study.

\section{REFERENCES}

1. Kementerian Kesehatan Republik Indonesia. Riset Kesehatan Dasar. Jakarta: Kemenkes RI; 2013.

2. Kulsum, I. D., \& Yunus, F. Sindrom Metabolik pada Penyakit Paru Obstruktif Kronik (PPOK). J Respir Indo. 2016; 36(1) : 47-59.

3. Perhimpunan Dokter Paru Indonesia. Penyakit Paru Obstruktif Kronik (PPOK) Edisi Buku Lengkap, Pedoman Diagnosis dan Penatalaksanaan di Indonesia. Jakarta: Perhimpunan Dokter Paru Indonesia; 2011.
4. Kementerian Kesehatan Republik Indonesia. Modul Penggunaan Obat Rasional. Jakarta: Kemenkes RI; 2011.

5. Banyu Aji, R. Evaluasi Penggunaan Bronkodilator dan Kortikosteroid pada Pasien Penyakit Paru Obstruktif Kronik (PPOK) di Instalasi Rawat Inap RSUP Fatmawati Periode 2018. Institut Sains dan Teknologi Nasional, Jakarta; 2019.

6. Andayani, T. M. Farmakoekonomi Prinsip dan Metodologi. Yogyakarta: Bursa Ilmu; 2013.

7. Direktorat Jenderal Bina Kefarmasian dan Alat Kesehatan. Pedoman Penerapan Kajian Farmakoekonomi. Jakarta: Kemenkes RI; 2013

8. Salawati, L. Hubungan Merokok Dengan Derajat Penyakit Paru Obstruksi Kronik. Jurnal Kedokteran Syiah Kuala. 2016; 16(3) : 165-169.

9. Riley, C. M., \& Sciurba, F. C. Diagnosis and Outpatient Management of Chronic Obstructive Pulmonary Disease: A Review. JAMA. 2019; 321(8), 786-797.

10. Wisman, B. A., Mardhiyah, R., \& Tenda, E. D. Pendekatan Diagnostik dan Tatalaksana Penyakit Paru Obstruktif Kronik GOLD D: Sebuah Laporan Kasus; 2015.

11. Pleasants, R. A., Wang, T., Xu, X., Beiko, T., Bei, H., Zhai, S., \& Drummond, M. B. Nebulized Corticosteroids in the Treatment of COPD Exacerbations: Systematic Review, Meta-Analysis, and Clinical 
Perspective. Respiratory Care. 2018; 63(10) : 1302-1310.

12. Lisa, T. G., Saad, A., \& Suyanto, S. Profil Penderita Penyakit Paru Obstruktif Kronik (Ppok) yang Dirawat Inap di RSUD Arifin Achmad Provinsi Riau Tahun 2013. Jurnal Online Mahasiswa Fakultas Kedokteran Universitas Riau. 2015; 2(2) : 1-13.

13. Prodyanatasari, A. Optimalisasi Energi Gelombang Elektromagnetik Melalui Terapi Infrared Pada Penderita Penyakit Paru Obstruktif Kronik. Jurnal Wiyata. Penelitian Sains dan Kesehatan. 2017; 2(1) : 59-66.

14. Sutanto, R. P. Penyakit paru obstruktif kronis dengan gejala pre hipertensi pada pasien laki-laki lanjut usia. Jurnal Medula. 2013; 1(04) : 94-100.

15. Mahawati, E. Laporan akhir disertasi doktor 2014: instrumen deteksi dini paparan kronis pestisida dalam pengendalian faktor risiko ppok (penyakit paru obstruktif kronis) pada petani di kecamatan gubug, tanggungharjo dan tegowanu kabupaten grobogan. Disertasi doktor 2014. Retrieved from http://eprints.dinus.ac.id/15111/ 